\title{
Primary melanoma of the vagina. A clinical case
}

\author{
Vajinanin primer melanomu. Bir klinik vaka
}

\author{
Judit Albareda ${ }^{1}$, Clara Olier², Isabel Alemany ${ }^{3}$ \\ ${ }^{\prime}$ Department of Obstetrics and Gynaecology, Hospital Universitario Fundacion Alcorcon, Madrid, Spain \\ ${ }^{2}$ Department of Medical Oncology, Hospital Universitario Fundacion Alcorcon, Madrid, Spain \\ ${ }^{3}$ Department of Pathology, Hospital Universitario Fundacion Alcorcon, Madrid, Spain
}

\section{Abstract}

Primary melanoma of the vagina is a rare neoplasm that appears in the $6^{\text {th }}$ and $7^{\text {th }}$ decades of life. It has a poor prognosis, for which there is no consensus regarding treatment; indeed, the literature describes a number of therapeutic options. This paper describes a patient with vaginal melanoma treated by local excision and immunotherapy.

(J Turkish-German Gynecol Assoc 2011; 12: 50-2)

Key words: Vaginal neoplasms, melanoma, treatment, prognosis

Received: 27 May, 2010

Accepted: 27 June, 2010

\section{Özet}

Vajinanın primer melanomu, yaşamın 6. ve 7. dekatında ortaya çıkan nadir bir neoplazmadır. Prognozu kötü nadir bir durum olup bu nedenle tedavisi hakkında bir fikir birliği yoktur; aslında literatürde birçok tedavi seçeneği tarif edilmektedir. Bu makalede lokal eksizyon ve immünoterapi ile tedavi edilen vajinal melanomlu bir hasta anlatılmaktadır. (J Turkish-German Gynecol Assoc 2011; 12: 50-2)

Anahtar kelimeler: Vaginal neoplazma, melanoma, tedavi, prognoz Geliş Tarihi: 27 Mayıs 2010

Kabul Tarihi: 27 Haziran 2010

\section{Introduction}

Vaginal melanoma is an uncommon form of melanoma, affecting an area not exposed to ultraviolet radiation (1). About $1.6 \%$ of melanomas appear on the genitals (1), and some $0.3-0.8 \%$ on the vagina $(2,3)$. Although melanoma is the second most common neoplasm of the vagina, it represents less than $3 \%$ of all neoplasms involving this area $(3,4)$. It mainly affects postmenopausal women in their $6^{\text {th }}$ and $7^{\text {th }}$ decade of life (5) and usually has no accompanying symptoms. However, some vaginal melanomas can lead to vaginal bleeding and an increase in discharge, and on some occasions a palpable mass can be felt (6). Amelanocytic melanomas are an uncommon form, making up about $2 \%$ of all vaginal melanomas (7).

Vaginal melanomas are usually localised in the lower third of the vagina and appear as multicentric, somewhat elevated lesions. They are very aggressive tumours and overall survival rates are very low. Independent of the treatment given, overall survival of five years is 5-25\% (4). This type of tumour carries a high risk of long distance metastases and local recurrence shortly after surgery; disease-free time is therefore usually short (8). The rarity of this condition means treatment is not well defined. Local excision, radical surgery, radiotherapy, chemotherapy and immunotherapy, or some combination of these, have been described by different authors (6).

The present work describes a patient with vaginal melanoma, the treatment provided, and a review of the pertinent literature in PubMed (Medline).

\section{Clinical case}

A 63 year-old patient with a background of adenocarcinoma of the endometrium (FIGO 1A G2), treated surgically for this condition at our centre in 2004, attended a routine follow-up appointment in March 2009, during which a hyperpigmented, multifocal, slightly ulcerated lesion affecting the lower third of the vagina (posterior wall) was detected. This lesion was under $3 \mathrm{~cm}$ in diameter and in contact with the external edge of the vagina (Fig. 1). The remainder of the vagina was free of disease. No palpable inguinal lymphatic ganglia were detected, and a pelvic examination was normal. The patient was asymptomatic and showed no skin lesions suspicious of melanoma. A biopsy of the affected area returned a result of squamous mucosa with melanoma and the presence of round cells. Immunohistochemical analysis returned positive results for HMB-45 and Melan-A (Table 1). A thoracic-abdominal-pelvic CT scan was normal.

The patient was treated surgically, involving complete excision of the affected vagina with a safety margin of $2 \mathrm{~cm}$. Bilateral inguinal lymphadenectomy was also performed.

Histological analysis returned a result of vaginal melanoma in the vertical growth phase, with three nodular lesions measuring 1.3, 0.5 and $1.5 \mathrm{~cm}$ along their longest axes. The maximum thickness of the lesion was $9 \mathrm{~mm}$. Extensive perineural invasion was noted with a mitotic index of four mitoses per 10 high power field (Fig. 2, 3). The resection margins were histologically free of neoplastic involvement. The inguinal lymphatic glands were negative. The TNM stage was T4a N0 M0 (stage IIB).

Given the risk of local recurrence and distant metastatic disease, surgery was followed by high dose interferon alpha-2b treatment according to Kirkwood (9) (20 mUI/m² i.v. once per day for 4 weeks, followed by a maintenance dose of $10 \mathrm{mUi} /$ $\mathrm{m}^{2}$ s.c. three times a week until week 48 after surgery) with the aim of lengthening the period of disease-free survival. In a PET CT scan performed seven months after surgery, the patient showed submillimetric pulmonary lesions compatible

Address for Correspondence / Yazışma Adresi: Uzm. Dr. Judit Albareda, Budapest 1 St 28922 Alcorcon, Spain 
Table 1. Immunohistochemical analysis

\begin{tabular}{|l|c|}
\hline Vimentin & positive \\
\hline EMA & focally positive \\
\hline HMB-45 & positive \\
\hline Melan-A & positive \\
\hline CD3 & positive \\
\hline CD20 & negative \\
\hline CD45 & negative \\
\hline CD79 alpha & negative \\
\hline CD 34 & negative \\
\hline CD68 & negative \\
\hline CD10 & negative \\
\hline Chromogranin & negative \\
\hline Synaptophysin & negative \\
\hline Desmin & negative \\
\hline Actin HHF-35 & negative \\
\hline Oestrogen receptor & negative \\
\hline Progesterone receptor & negative \\
\hline CMA 5-2 & negative \\
\hline CKAE1-AE3 & negative \\
\hline
\end{tabular}

with metastases; this was confirmed histologically following radioguided punction. Palliative chemotherapy was provided. At one year post diagnosis the patient is alive but with disease.

\section{Discussion}

Primary melanoma of the vagina is a rare neoplasm that usually affects adult women. The literature only describes some 250 cases (10), which explains the lack of consensus regarding its treatment (11). The condition normally affects the lower third of the vagina (10); lesions are usually multifocal and in $2 \%$ of cases, amelanocytic (7).

Studies have shown that vaginal melanoma usually appears in the $6^{\text {th }}$ and $7^{\text {th }}$ decades of life (10). At the time of diagnosis the present patient was 63 years old. These tumours commonly have no accompanying symptoms (11) and are usually found by chance, as in the present case. The most common symptoms, when they occur, are vaginal bleeding and an increase in vaginal discharge; in some cases a palpable mass can be detected (2).

The prognosis of patients with melanoma is poor. The literature describes the five year survival as around $25 \%$ (2). In a meta-analysis performed by Buchanan et al., the overall five year survival was $13-19 \%$. Only two patients survived 10 years and both suffered recurrences that required various treatments (11). A number of factors have been associated with a poorer prognosis, the most important of which appears to be tumour size (10). Tumours $<3 \mathrm{~cm}$ in diameter localised in the lower third of the vagina seem to be associated with better overall survival (mean 41 months),

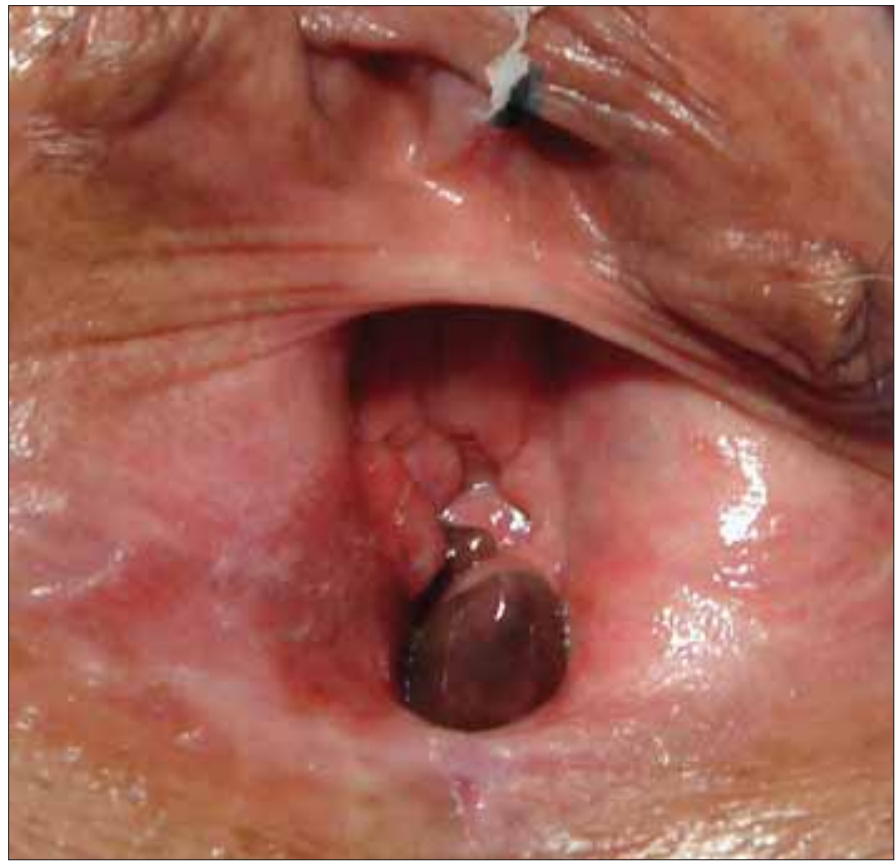

Figure 1. Macroscopic appearance of vaginal melanoma lesion

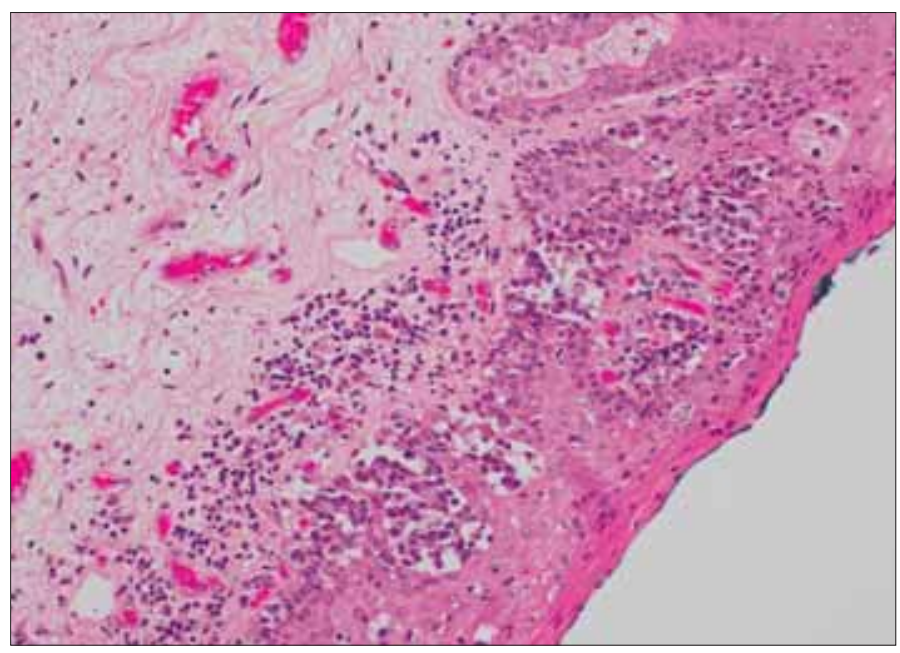

Figure 2. Staining with haematoxylin-eosin (100x). Note the nests of atypical melanocytic cells at the junction between the epithelium and the subepithelial connective tissue, reflecting neoplastic activity

probably because of the possibility of surgical removal with tumour-free margins. In tumours $\geq 3 \mathrm{~cm}$, achieving tumour-free margins is more difficult, and survival is about 12 months (11).

The thickness of the tumour does not appear to affect overall survival. Tumours showing $\geq 6 \mathrm{~mm}$ invasion are associated with a mean survival of 16 months, while those showing $<6 \mathrm{~mm}$ invasion are associated with a mean survival of 23 months $(\mathrm{p}<0.288)(11)$. Certainly, cell type, number of mitotic cells, ulceration, vascular involvement and amelanosis all appear to affect survival (12).

The FIGO staging system is probably not the optimum for use with vaginal cancers since it does not contemplate tumour size (which is important in vaginal melanoma) or the study of the lymph glands (13). Some authors suggest that the Breslow 


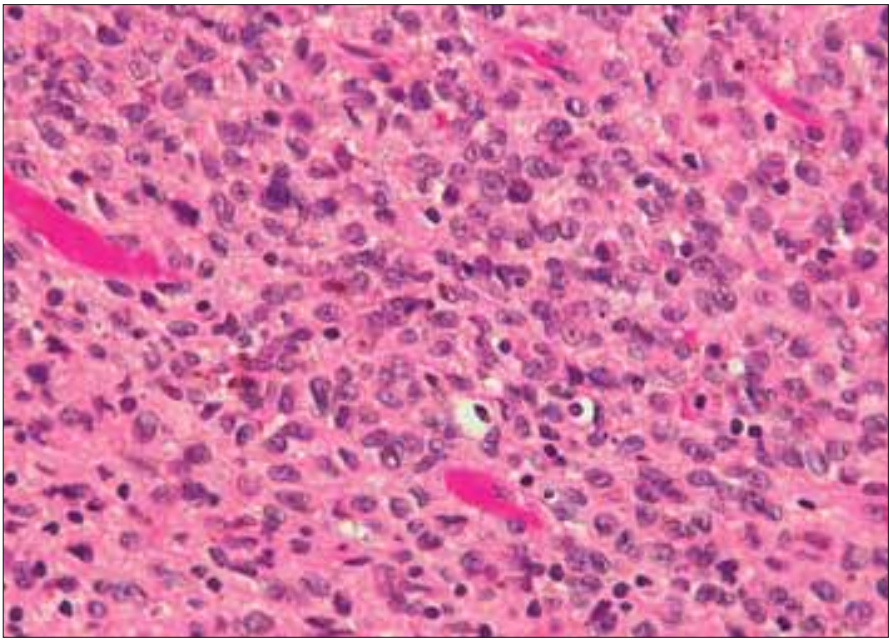

Figure 3. Staining with haematoxylin-eosin (400x). Note atypical cells of variable size and nuclear morphology, with coarse chromatin and occasional prominent nucleoli. Note the intracytoplasmic granular pigment (melanin)

method, which is valid for cutaneous melanomas, could be used in the early stages of vaginal melanomas. Clark levels, however, do not seem applicable given the absence of dermal and subcutaneous papillary and reticular structures (4, 10). Thus, the staging of vaginal melanomas can be difficult, with the microstaging method of Breslow (14) perhaps being the best available (10).

Treatment options include local excision (8), radical excision with inguinofemoral and/or pelvic lymphadenectomy (6), radiotherapy (15), chemotherapy, and immunotherapy $(5,9,16)$. Most authors suggest surgical treatment (1,3,10,17), although the benefit of radical surgery over conservative surgery has not been demonstrated (always supposing the margins are tumourfree) $(10,11)$. Non-tumour-free resection margins favour local recurrence and are associated with a poorer prognosis (11). No difference has been demonstrated between radical and conservative surgery either in terms of overall survival or disease-free survival.

Adjuvant pelvic radiotherapy and brachytherapy may help in the locoregional control of the disease (10). Exenteration and/ or radiotherapy may be useful when dealing with large tumours. Radiotherapy and chemotherapy are indicated when a tumour is nonresectable (10), although the role of chemotherapy in patients with distant metastases has not been established. Although lymphadenectomy is controversial (17), some authors advise pelvic lymphadenectomy for tumours affecting the mid and upper thirds of the vagina, and inguinal lymphadenectomy for those affecting the lower third (4). However, the pelvic ganglia are not usually involved. Examination of the sentinel node, normally a matter of course for melanoma in other locations, should provide the information necessary to identify which patients require complete lymphadenectomy (1). The sentinel node illustrates the status of the regional ganglia, obviating the need to perform exhaustive lymphadenectomy and thus avoiding the morbidity this entails. In addition, it allows the presence of micrometastases to be diagnosed. If the surgical team has sufficient experience, sentinel node examination before lymphadenectomy could therefore be of benefit; unfortunately no such experience was available in the context of vaginal melanoma at our centre when the present patient underwent surgery.
In conclusion, vaginal melanomas are uncommon, highly aggressive tumours that are associated with poor overall survival. The chance of local recurrence following surgical treatment is around 80\%; the risk of distant metastases is also very high. There is no consensus regarding treatment, but the combination of different therapies, plus local excision of the lesion and investigation of the sentinel node, if possible, would appear to be a reasonable option.

This work is dedicated to the memory of Dr. Antonio López Salvà, 1951-2010.

\section{Acknowledgements}

The authors thank the librarian Ms. Eulalia Grifol Clar for excellent assistance with the literature search.

\section{Conflict of interest}

No conflict of interest is declared by authors.

\section{References}

1. Miner TJ, Delgado R, Zeisler J, Busam K, Alektiar K, Barakat R et al Primary vaginal melanoma: a critical analysis of therapy. Ann Surg Oncol. 2004; 11: 34-9.

2. Weinstock MA. Malignant melanoma of the vulva and vagina in the United States: patterns of incidence and population-based estimates of survival. Am J Obstet Gynecol 1994; 171: 1225-30.

3. Takai N, Kai N, Hirata Y, Kashima K, Narahara H. Primary malignant melanoma of the vagina. Eur J Gynaecol Oncol 2008; 29: 558-9.

4. Piura B. Management of primary melanoma of the female urogenital tract. Lancet Oncol 2008 10; 9: 973-81.

5. Baloglu A, Bezircioglu I, Cetinkaya B, Yavuzcan A. Primary malignant melanoma of the vagina. Arch Gynecol Obstet 2009;26.

6. Gökaslan H, Şişmanoğlu A, Pekin T, Kaya H, Ceyhan N. Primary malignant melanoma of the vagina: a case report and review of the current treatment options. Eur J Obstet Gynecol Reprod Biol 2005; 121: 243-8.

7. Grenader T, Isacson R, Reinus C, Rosengarten O, Barenholz O, Hyman J, et al. Primary amlanotic melanoma of the vagina. Onkologie 2008; 31: 474-6.

8. Moodley M, Daya M, Moodley J. Vaginal malignant melanoma: a case report and literature review. Int J Gynecol Cancer 2004; 14: 687-9. [CrossRef]

9. Kirkwood JM, Strawderman MH, Ernstoff MS, Smith TJ, Borden EC Blum RH. Interferon alfa-2b adjuvant therapy of high-risk resected cutaneous melanoma: the Eastern Cooperative Oncology Group Trial EST 1684. J Clin Oncol 1996; 14: 7-17.

10. Piura B, Rabinovich A, Yanai-Inbar I. Primary malignant melanoma of the vagina: case report and review of literature. Eur J Gynaecol Oncol 2002; 23: 195-8.

11. Buchanan DJ, Schlaerth J, Kurosaki T. Primary vaginal melanoma: thirteen-year disease-free survival after wide local excision and review of recent literature. Am J Obstet Gynecol 1998; 178: 1177-84. [CrossRef]

12. Petru E, Nagele F, Czerwenka K, Graf AH, Lax S, Bauer M et al. Primary malignant melanoma of the vagina: long-term remission following radiation therapy. Gynecol Oncol 1998; 70: 23-6.

13. FIGO Committee on Gynecologic Oncology. Current FIGO staging for cancer of the vagina, fallopian tube, ovary, and gestational trophoblastic neoplasia. Int J Gynaecol Obstet 2009; 105: 3-4. [CrossRef]

14. Breslow A. Thickness, cross-sectional areas and depth of invasion in the prognosis of cutaneous melanoma. Ann Surg. 1970; 172: 902-8. [CrossRef]

15. Mukhopadhyay S, Ghosh S, Siddhartha D, Mitra PK. A clinicopathological study of malignant melanoma with special reference to atypical presentation. Indian J Pathol Microbiol 2008; 51: 485-8. [CrossRef]

16. Androutsopoulos G, Adonakis G, Ravazoula P, Kourounis G. Primary malignant melanoma of the vagina: a case report. Eur J Gynaecol Oncol 2005; 26: 661-2.

17. Sugiyama VE, Chan JK, Kapp DS. Management of melanomas of the female genital tract. Curr Opin Oncol 2008; 20: 565-9. [CrossRef] 